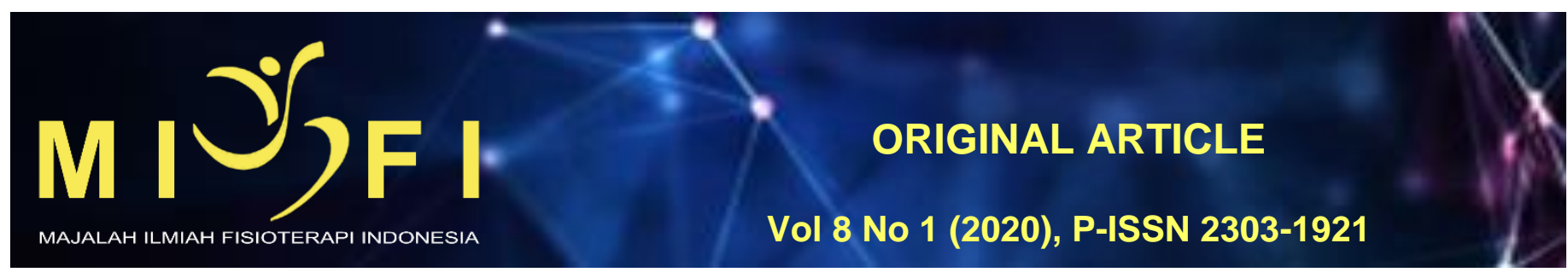

\title{
HUBUNGAN AKTIVITAS FISIK DENGAN KUALITAS TIDUR PADA USIA LANJUT DI DESA SUMERTA KELOD
}

Anak Agung Istri Dewi ${ }^{1}$, Nila Wahyuni ${ }^{2}$, Ni Luh Nopi Andayani ${ }^{3}$, I Putu Adiartha Griadhi ${ }^{4}$

${ }^{1}$ Program Studi Sarjana Fisioterapi dan Profesi Fisioterapi, Fakultas Kedokteran Universitas Udayana

2,4 Departemen Ilmu Faal, Fakultas Kedokteran Universitas Udayana

${ }^{3}$ Departemen Fisioterapi, Fakultas Kedokteran Universitas Udayana aistdewi@gmail.com

\begin{abstract}
ABSTRAK
Gangguan tidur merupakan masalah yang sering dialami oleh usia lanjut yang berdampak terhadap kualitas tidur. Faktor yang dapat mempengaruhi kualitas tidur adalah aktivitas fisik. Aktivitas fisik yang rutin dilakukan dapat meningkatkan kualitas tidur. Tujuan dari penelitian ini untuk mengetahui hubungan aktivitas fisik dengan kualitas tidur pada usia lanjut di Desa Sumerta Kelod. Rancangan penelitian yang digunakan adalah analitik cross sectional dengan teknik consecutive sampling. Jumlah sampel sebanyak 56 usia lanjut (23 laki-laki dan 23 perempuan) berusia 60-74 tahun. Variabel bebas yang diukur adalah aktivitas fisik dengan menggunakan kuesioner Baecke Index dan variabel terikat adalah kualitas tidur dengan menggunakan kuesioner PSQI. Uji hipotesis yang digunakan adalah Chi-Square Test dengan hasil nilai $p=0,006(p<0,05)$. Simpulan dari penelitian ini adalah terdapat hubungan yang bermakna antara aktivitas fisik dengan kualitas tidur pada usia lanjut di Desa Sumerta Kelod. Diharapkan pada penelitian selanjutnya untuk mengontrol jenis kelamin pada sampel yang dapat mempengaruhi hasil penelitian.
\end{abstract}

Kata Kunci: aktivitas fisik, kualitas tidur, usia lanjut

\section{THE CORRELATION BETWEEN PHYSICAL ACTIVITY AND SLEEP QUALITY AMONG ELDERLY IN SUMERTA KELOD VILLAGE}

\begin{abstract}
Sleep disturbance is a problem that is often experienced by the elderly who have an impact on sleep quality. Factors that can affect the quality of sleep are physical activity. Physical activity carried out regularly can improve sleep quality. The purpose of this research was to determine the correlation between physical activity and sleep quality among elderly in Sumerta Kelod Village. The research design used was cross sectional analytic with consecutive sampling. The number of samples is 56 elderly (23 men and 23 women) aged 60-74 years. The independent variables measured were physical activity using the Baecke Index questionnaire and the dependent variable was the quality of sleep using the PSQI questionnaire. The hypothesis test used is Chi-Square Test with the value of $p=0.006(p<0.05)$. The conclusion of this study is that there is a significant relationship between physical activity and sleep quality among elderly in Sumerta Kelod Village. Further research needs to control the sex of samples that can influence the results of the research.
\end{abstract}

Keywords: physical activity, sleep quality, elderly 


\section{PENDAHULUAN}

Usia lanjut menurut World Health Organization (WHO) adalah orang yang berusia 60 tahun atau lebih, yang diklasifikasikan menjadi empat yaitu middle age berusia 45-59 tahun, elderly berusia 60-74 tahun, old berusia 70-90 tahun dan very old berusia lebih dari 90 tahun ${ }^{1}$. Usia lanjut merupakan suatu periode yang menunjukkan adanya kemunduran sejalan dengan berjalannya waktu². Jumlah penduduk lanjut usia mengalami peningkatan seiring dengan tingginya harapan hidup. Analisis usia lanjut di Indonesia menurut Kementerian Kesehatan RI tahun 2017 memprediksi bahwa presentase penduduk usia lanjut akan mengalami peningkatan. Meningkatnya populasi usia lanjut akan menyebabkan semakin banyak masalah kesehatan yang dialami karena proses penuaan. Proses penuaan ditandai dengan menghilangnya kemampuan jaringan untuk memperbaiki kerusakan yang diderita dan mempertahankan fungsi normalnya ${ }^{3}$.

Masalah kesehatan yang sering ditemui pada usia lanjut adalah gangguan tidur ${ }^{4}$. Usia lanjut memerlukan waktu yang lebih lama untuk memulai tidur tetapi memiliki waktu yang pendek untuk tidur dengan nyenyak ${ }^{5}$. Setiap tahun dilaporkan sekitar $20-50 \%$ orang dewasa mengalami gangguan tidur dan sekitar $17 \%$ mengalami gangguan tidur yang serius sedangkan pada usia lanjut prevalensi gangguan tidur cukup tinggi sekitar $67 \%{ }^{6}$. Hasil penelitian yang dilakukan di Iran menyebutkan bahwa sebesar $86,2 \%$ dari 390 usia lanjut dengan rata-rata usia 60 tahun ke atas mengalami gangguan tidur dan lebih dari setengah usia lanjut membutuhkan waktu sekitar 20 menit untuk memulai tidur ${ }^{7}$. Gangguan tidur yang terjadi pada usia lanjut tentunya akan mempengaruhi kualitas tidur. Kualitas tidur merupakan suatu kondisi dimana tidur yang dijalani seseorang dapat memberikan kebugaran, kesegaran dan kepuasan ketika terbangun. Tidur yang cukup dipengaruhi oleh jumlah jam tidur (kuantitas) dan kedalaman tidur (kualitas) ${ }^{8}$. Faktor-faktor yang mempengaruhi kualitas tidur pada usia lanjut antara lain usia, depresi, penyakit, penggunaan obat-obatan, gaya hidup, lingkungan serta aktivitas fisik ${ }^{9,10}$. Pemeliharaan kualitas tidur merupakan aspek penting peningkatan kesehatan usia lanjut untuk memastikan pemulihan fungsi tubuh sampai tingkat fungsional sehingga dapat melakukan aktivitas dan meningkatkan kualitas hidup ${ }^{11}$.

Aktivitas fisik adalah salah satu cara yang dapat dilakukan untuk meningkatkan kualitas tidur pada usia lanjut. Aktivitas fisik merupakan semua pergerakan sebagai hasil dari kontraksi otot rangka yang memerlukan energi ${ }^{12}$. Aktivitas fisik terdiri dari gerakan kegiatan bebas, terstruktur, kegiatan olahraga maupun kegiatan sehari-hari. Usia lanjut dengan aktivitas fisik yang kurang dan tidak terstruktur akan mempengaruhi pengurangan waktu tidur atau kualitas tidur. Perubahan tidur normal yang dialami usia lanjut adalah pada tahap Non Rapid Eye Movement (NREM) 3 dan 4. Usia lanjut hampir tidak memiliki tahap 4 atau tidur dalam ${ }^{13}$. Aktivitas fisik menyebabkan peningkatan konsumsi energi, sekresi endorphin dan suhu tubuh yang dapat meningkatkan kebutuhan tidur dan proses penyembuhan tubuh ${ }^{14}$. Semakin banyak energi yang dikonsumsi maka semakin besar kemungkinan restorasi. Usia lanjut yang aktif beraktivitas fisik diharapkan dapat meningkatkan kebutuhan tidur untuk memulihkan dan memperbaiki tubuh serta menyeimbangkan energi yang dikonsumsi ${ }^{15}$. Aktivitas fisik yang dilakukan dengan rutin akan memberikan dampak yang positif bagi kesehatan karena dapat membuat metabolisme menjadi baik, peredaran darah lancar sehingga tidur dapat lebih tenang dan nyaman ${ }^{16}$. Melalui aktivitas fisik dapat merangsang aktivitas saraf simpatis dan aktivitas saraf parasimpatis sehingga hormon adrenalin, norepinefrin dan katekolamin menurun ${ }^{17}$. Sistem saraf simpatis diaktivasi ketika beraktivitas fisik yang menyebabkan peningkatan denyut jantung, sedangkan sistem saraf parasimpatis menyebabkan proses pemulihan ${ }^{18}$. Aktivitas saraf parasimpatis akan menyebabkan terjadinya vasodilatasi pembuluh darah yang menyebabkan oksigen ke otak dan seluruh tubuh menjadi lancar sehingga menyebabkan peningkatan relaksasi ${ }^{19}$.

Aktivitas fisik dan istirahat saling berkaitan karena apabila tidak aktif beraktivitas maka akan mempengaruhi waktu istirahat sehingga akan menyebabkan gangguan tidur dan akan mempengaruhi pengurangan waktu tidur dan kualitas tidur 5 . Pada penelitian yang dilakukan oleh Rosdianti et al (2018) tentang Hubungan Activity of Daily Living dengan Kualitas Tidur pada Usia lanjut di Panti Sosial Tersna Werdha Khusnul Khotimah Pekanbaru dikatakan bahwa dari 49 responden yang terlibat sekitar $75,5 \%$ dengan ADL (Activity of Daily Living) mandiri memiliki kualitas tidur yang baik. Usia lanjut dengan aktivitas fisik yang baik akan memiliki kondisi tubuh yang lebih bugar sehingga kemampuan untuk tidur dengan baik semakin meningkat. Namun berbeda dengan penelitian yang dilakukan oleh Rachmawati Pangulu (2015) yang mengatakan bahwa tidak ada hubungan antara aktivitas fisik dengan kejadian insomnia pada usia lanjut di Panti Sosial Tresna Werdha Yogyakarta Unit Budi Luhur. Hal tersebut disebabkan karena selain aktivitas fisik terdapat berbagai faktor yang dapat menyebabkan insomnia. Masih terdapat berbagai faktor atau variabel yang dapat menyebabkan insomnia yang belum diteliti pada penelitian tersebut sehingga perlu dikembangkan kembali.

Berdasarkan pemaparan latar belakang diatas, peneliti ingin mengetahui hubungan aktivitas fisik dengan kualitas tidur pada usia lanjut. Hal ini menarik untuk diteliti, dilihat dari adanya perbedaan pada penelitian sebelumnya terkait ada atau tidak hubungan antara kedua variabel tersebut.

\section{METODE}

Rancangan penelitian yang digunakan adalah analitik cross sectional. Penelitian ini dilaksanakan pada bulan April-Mei 2019 di tiga banjar yang berada di Desa Sumerta Kelod. Sampel penelitian dipilih berdasarkan kriteria inklusi yaitu bersedia menjadi subjek penelitian, berusia 60-74 tahun, memiliki kognitif yang baik dengan skor MMSE minimal 24, tidak mengalami depresi dengan skor GDS (Geriatric Depression Scale) maksimal 4 dan tidak menggunakan obatobatan. Sementara itu, kreteria eksklusi yaitu merokok dan minum alkohol, mengalami nyeri, asma, gatal-gatal, inkontinensia urine. Penelitian ini menggunakan teknik consecutive sampling dengan total sampel 56 orang.

Variabel independen pada penelitian ini dilakukan pengukuran dengan menggunakan kuesioner Beacke Index untuk mengetahui tingkat aktivitas fisik yang dimiliki sedangkan variabel dependen diukur dengan menggunakan kuesioner Pittsburgh Sleep Quality Index (PSQI) untuk mengetahui skor kualitas tidur. 
Analisis data pada penelitian ini menggunakan software SPSS yang dibagi menjadi dua yaitu analisis univariat untuk menggambarkan distribusi frekuensi tiap variabel dan analisis bivariat untuk mengetahui hubungan antara kedua variabel dengan metode analisis menggunakan Chi Square Test.

HASIL

Berikut adalah hasil penelitian berdasarkan distribusi karakteristik sampel antara lain usia, jenis kelamin aktivitas fisik dan kualitas tidur pada usia lanjut di Desa Sumerta Kelod yang berjumlah 56 responden.

\begin{tabular}{ccc} 
Tabel 1. Distribusi Frekuensi berdasarkan Usia dan Jenis Kelamin \\
\cline { 2 - 3 } Usia (tahun) & Frekuensi (n) & Presentase (\%) \\
\hline $60-64$ & 19 & 33,9 \\
$65-69$ & 19 & 33,9 \\
$70-74$ & 18 & 32,1 \\
Jumlah & 56 & 100 \\
\hline Jenis Kelamin & Frekuensi (n) & Presentase (\%) \\
\hline Laki-laki & 23 & 41,1 \\
Perempuan & 33 & 58,9 \\
Jumlah & 56 & 100 \\
\hline
\end{tabular}

Berdasarkan tabel 1 dapat diketahui jumlah responden berdasarkan rentang usia hampir sama yakni usia 60 64 tahun berjumlah 19 orang (33,9\%), usia 65-69 tahun berjumlah 19 orang (33,9\%) sedangkan usia 70-74 tahun berjumlah 18 orang $(32,1 \%)$. Dilihat berdasarkan jenis kelamin, responden perempuan mendominasi dibandingkan dengan laki-laki. Jumlah responden perempuan yakni sebanyak 33 orang $(58,9 \%)$ sedangkan responden laki-laki sebanyak 23 orang $(41,1 \%)$.

\begin{tabular}{ccccc}
\multicolumn{4}{c}{ Tabel 2. Distribusi Frekuensi Aktivitas Fisik Berdasarkan Usia } \\
\cline { 1 - 4 } $\begin{array}{c}\text { Usia } \\
\text { (tahun) }\end{array}$ & Ringan & Sktivitas Fisik & \multirow{2}{*}{ Total } \\
\cline { 2 - 4 } & Redang & Tinggi & \\
\hline $60-64$ & $4(21,1 \%)$ & $10(52,6 \%)$ & $5(26,3 \%)$ & $19(100 \%)$ \\
$65-69$ & $5(26,3 \%)$ & $8(42,1 \%)$ & $6(31,6 \%)$ & $19(100 \%)$ \\
$70-74$ & $7(38,9 \%)$ & $8(44,4 \%)$ & $3(16,7 \%)$ & $18(100 \%)$ \\
\hline Total & $16(28,6 \%)$ & $26(46,4 \%)$ & $14(25,0 \%)$ & $56(100 \%)$ \\
\hline
\end{tabular}

Berdasarkan tabel 2, Hasil penelitian ini menunjukkan masing-masing rentang usia 60-74 tahun memiliki kategori aktivitas fisik yang berbeda-beda. Aktivitas fisik ringan lebih banyak dimiliki oleh responden berusia 70-74 tahun sebesar 38,9\%, aktivitas fisik sedang lebih banyak pada responden berusia $60-64$ tahun sebesar $52,6 \%$ sedangkan aktivitas fisik tinggi lebih banyak pada responden berusia 65-69 tahun sebesar 31,6\%.

Tabel 3. Distribusi Frekuensi Aktivitas Fisik Berdasarkan Jenis Kelamin

\begin{tabular}{ccccc}
\hline Jenis & \multicolumn{2}{c}{ Aktivitas Fisik } & Total \\
\cline { 2 - 4 } Kelamin & Ringan & Sedang & Tinggi & \\
\hline Perempuan & $10(30,3 \%)$ & $17(51,5 \%)$ & $6(18,2 \%)$ & $33(100 \%)$ \\
Laki-laki & $6(26,1 \%)$ & $9(39,1 \%)$ & $8(34,8 \%)$ & $23(100 \%)$ \\
\hline Total & $16(28,6 \%)$ & $26(46,4 \%)$ & $14(25,0 \%)$ & $56(100 \%)$ \\
\hline
\end{tabular}

Berdasarkan tabel 3, Hasil penelitian menunjukkan aktivitas fisik ringan didominasi oleh responden perempuan sebesar 30,3\%. Begitu pula untuk aktivitas fisik sedang didominasi oleh responden perempuan sebesar $51,5 \%$ sedangkan aktivitas fisik tinggi sebesar $34,8 \%$ didominasi oleh responden laki-laki.

Tabel 4. Distribusi Frekuensi Kualitas Tidur Berdasarkan Usia

\begin{tabular}{cccc}
\hline \multirow{2}{*}{$\begin{array}{c}\text { Usia } \\
\text { (tahun) }\end{array}$} & \multicolumn{2}{c}{ Kualitas Tidur } & Total \\
\cline { 2 - 3 } & Baik & Buruk & \\
\hline $60-64$ & $11(57,9 \%)$ & $8(42,1 \%)$ & $19(100 \%)$ \\
$65-69$ & $14(73,7 \%)$ & $5(26,3 \%)$ & $19(100 \%)$ \\
$70-74$ & $13(72,2 \%)$ & $5(27,8 \%)$ & $18(100 \%)$ \\
\hline Total & $38(67,9 \%)$ & $18(32,1 \%)$ & $56(100 \%)$ \\
\hline
\end{tabular}

Berdasarkan Tabel 4, kualitas tidur baik lebih banyak dimiliki oleh responden dengan usia 65-69 tahun sebesar $73,7 \%$ dan kualitas tidur buruk pada responden dengan usia 60-64 tahun sebesar 42,1\%.

Tabel 5. Distribusi Frekuensi Kualitas Tidur Berdasarkan Jenis Kelamin

\begin{tabular}{cccc}
\hline Jenis & \multicolumn{2}{c}{ Kualitas Tidur } & Total \\
\cline { 2 - 3 } Kelamin & Baik & Buruk & \\
\hline Perempuan & $23(69,7 \%)$ & $10(30,3 \%)$ & $33(100 \%)$ \\
Laki-laki & $15(65,2 \%)$ & $8(34,8 \%)$ & $23(100 \%)$ \\
\hline Total & $38(67,9 \%)$ & $18(32,1 \%)$ & $56(100 \%)$ \\
\hline
\end{tabular}


Berdasarkan tabel 5, Kualitas tidur baik lebih banyak pada respoden perempuan sebesar $69,7 \%$ dan kualitas tidur buruk lebih banyak pada responden laki-laki sebesar $34,8 \%$.

\begin{tabular}{|c|c|c|c|c|}
\hline \multirow{2}{*}{$\begin{array}{l}\text { Aktivitas } \\
\text { Fisik }\end{array}$} & \multicolumn{2}{|c|}{ Kualitas Tidur } & \multirow[t]{2}{*}{ Total } & \multirow[t]{2}{*}{$p$} \\
\hline & Baik & Buruk & & \\
\hline Ringan & $6(37,5 \%)$ & $10(62,5 \%)$ & $16(100 \%)$ & \\
\hline Sedang & $22(84,6 \%)$ & $4(15,4 \%)$ & 26 (100\%) & \\
\hline Tinggi & $10(71,4 \%)$ & $4(28,6 \%)$ & $14(100 \%)$ & \\
\hline Total & $38(67,9 \%)$ & $18(32,1 \%)$ & $56(100 \%)$ & 0,006 \\
\hline
\end{tabular}

Berdasarkan tabel 6 dari hasil uji statistik Chi Square Test menunjukkan bahwa bahwa usia lanjut dengan aktivitas fisik ringan berjumlah 16 orang yang memiliki kualitas tidur yang baik sebanyak 6 orang $(37,5 \%)$ dan kualitas tidur yang buruk sebanyak 10 orang (62,5\%). Sebagian besar usia lanjut memiliki aktivitas fisik sedang dengan jumlah 26 orang yang memiliki kualitas tidur yang baik sebanyak 22 orang $(84,6 \%)$ dan kualitas tidur yang buruk sebanyak 4 orang $(15,4 \%)$. Usia lanjut dengan aktivitas fisik tinggi berjumlah 14 orang yang memiliki kualitas tidur yang baik sebanyak 10 orang $(71,4 \%)$ dan kualitas tidur yang buruk sebanyak 4 orang $(28,6 \%)$.

\section{DISKUSI}

Hasil penelitian menunjukkan terdapat usia lanjut dengan rentang usia 60-64 tahun sebanyak 19 orang (33,9\%), rentang usia 65-69 tahun sebanyak 19 orang (33,9\%) dan rentang usia 70-74 tahun sebanyak 18 orang (32,1\%). Ketika memasuki usia lanjut akan terjadi proses degenaratif yang akan berdampak pada perubahan fisik maupun psikologis ${ }^{20}$. Masalah yang sering ditemukan pada usia lanjut adalah gangguan tidur yang dialami oleh usia lanjut berusia 60 tahun atau lebih baik pada perempuan ataupun laki-laki. Proses menua yang ditandai dengan perubahan anatomi dan fisiologis dapat menyebabkan waktu tidur efektif usia lanjut semakin berkurang ${ }^{7}$. Hasil penelitian menunjukkan sebanyak 33 orang (58,9\%) dari sampel adalah berjenis kelamin perempuan sedangkan 23 orang $(41,1 \%)$ adalah lakilaki. Distribusi jenis kelamin perempuan yang lebih besar disebabkan perbedaan usia harapan hidup antara laki-laki dan perempuan. Secara teoritis angka harapan hidup perempuan lebih tinggi daripada laki-laki sehingga keberadaan usia lanjut perempuan lebih banyak. Usia lanjut yang tinggal baik di desa maupun di kota, proporsi usia lanjut perempuan lebih tinggi daripada laki-laki21.

Berdasarkan aktivitas fisik, dari 56 responden terdapat 16 orang $(28,6 \%)$ dengan aktivitas fisik ringan, 26 orang $(46,4 \%)$ dengan aktivitas fisik sedang dan 14 orang $(25,0 \%)$ dengan aktivitas fisik tinggi. Aktivitas fisik ringan lebih banyak dimiliki oleh responden berusia 70-74 tahun sebesar 38,9\%, aktivitas fisik sedang lebih banyak pada usia lanjut berusia 60-64 tahun sebesar 52,6\% sedangkan aktivitas fisik tinggi lebih banyak pada usia lanjut berusia 65-69 tahun sebesar $31,6 \%$. Semakin bertambahnya usia pada usia lanjut akan berdampak pada ketidakmampuan untuk melakukan aktivitas fisik. Usia lanjut yang telah memasuki usia 70 tahun atau lebih adalah usia lanjut dengan resiko tinggi untuk mengalami penurunan dalam berbagai hal termasuk dalam melakukan aktivitas fisik ${ }^{3}$. Responden pada penelitian ini di setiap rentang usia memiliki level aktivitas fisik yang berbeda-beda. Responden pada rentang usia 70-74 tahun masih ada yang memiliki aktivitas fisik tinggi sebanyak 3 orang (16,7\%). Aktivitas fisik tinggi yang dimiliki oleh responden tersebut diperoleh dari perhitungan kuesioner Baecke Index yang dominan pada indeks olahraga dan indeks waktu senggang dan masih aktif dalam mengerjakan pekerjaan rumah tangga. Penuaan menyebabkan perubahan fisiologis yang berpengaruh pada organ-organ tubuh termasuk sistem muskuloskeletal yang dapat mempengaruhi aktivitas fisik. Aktivitas fisik yang dilakukan sehari-hari oleh usia lanjut dalam kategori sedang ataupun tinggi membutuhkan kondisi fisik yang baik, semakin baik kondisi fisik yang dimiliki maka semakin mudah dalam melakukan kegiatan ataupun aktivitas fisik ${ }^{22}$. Aktivitas fisik ringan didominasi oleh responden perempuan sebesar $30,3 \%$. Begitu pula untuk aktivitas fisik sedang didominasi oleh responden perempuan sebesar 51,5\% sedangkan aktivitas fisik tinggi sebesar 34,8\% didominasi oleh responden laki-laki. Hasil observasi menunjukkan bahwa responden laki-laki cenderung sering melakukan aktivitas duduk, berjalan, dan berolahraga berat dibandingkan perempuan. Responden laki-laki cenderung tidak pernah melakukan aktivitas rumah tangga dibandingkan perempuan. Tetapi, laki-laki cenderung lebih banyak yang masih bekerja dibandingkan dengan perempuan.

Berdasarkan distribusi kualitas tidur dari 56 responden terdapat 38 orang $(67,9 \%)$ dengan kualitas tidur yang baik sedangkan 18 orang $(32,1 \%)$ dengan kualitas tidur yang buruk. Kualitas tidur yang baik ditandai dengan tidak adanya kelelahan di siang hari, gelap di area mata, sakit kepala, mudah lelah, dan sering menguap dan mengantuk ${ }^{23}$. Sebagaian besar usia lanjut memiliki kualitas tidur yang baik karena kondisi tubuh yang optimal baik secara fisiologis dan psikologis. Berdasarkan hasil kuesioner PSQI didapatkan bahwa usia lanjut memiliki efisiensi tidur yang baik dimana usia lanjut tidak mengeluh bangun terlalu pagi. Pada komponen latensi tidur juga baik dimana usia lanjut tidak mengalami kesulitan dalam memulai tidur. Biasanya pada usia lanjut akan membutuhkan waktu 30-60 menit untuk memulai tidur dan terbangun terlalu pagi. Usia lanjut juga tidak mengalami gangguan tidur pada malam hari dimana mereka hanya terbangun sesekali untuk buang air kecil, kondisi lingkungan yang baik seperti tidak merasa kepanasan atau kedinginan. Selain itu usia lanjut tidak mengeluh mengalami nyeri, sesak, ataupun batuk yang mengganggu tidur. Usia lanjut juga tidak ada yang mengkonsumsi obat-obatan untuk membantu mempermudah tidur sehingga mereka tidak ada yang mengalami ketergantungan. Hal-hal tersebut yang menyebabkan kebutuhan tidur pada usia lanjut menjadi tercukupi sehingga dari hasil kuesioner total skor yang diperoleh adalah kualitas tidur baik.

Kualitas tidur baik lebih banyak dimiliki oleh responden dengan usia 65-69 tahun sebanyak 14 orang (73,7\%) dan kualitas tidur buruk pada responden dengan usia 60-64 tahun sebanyak 8 orang $(42,1 \%)$. Sedangkan berdasarkan jenis kelamin kualitas tidur baik lebih banyak pada respoden perempuan sebesar $69,7 \%$ dan kualitas tidur buruk lebih 
banyak pada responden laki-laki sebesar 34,8\%. Semakin bertambahnya usia seseorang maka semakin buruk kualitas tidur yang dimiliki. Usia merupakan salah satu faktor yang mempengaruhi kualitas tidur ${ }^{24}$. Tetapi pada penelitian ini kualitas tidur yang dimiliki responden pada masing-masing rentang usia dan jenis kelamin menunjukkan hasil yang bervariasi. Responden berusia 60-64 tahun memiliki kualitas tidur buruk dibandingkan responden berusia 65-69 tahun dan 70-74 tahun. Hal ini dapat disebabkan karena ada beberapa usia lanjut yang memerlukan waktu tidur lebih dari 7 jam yang kemungkinan disebabkan karena usia lanjut tersebut dapat beradaptasi dengan perubahan akibat proses penuaan yang terjadi pada dirinya ${ }^{9}$. Selain itu juga dapat disebabkan karena faktor lain seperti kelelahan dan lingkungan. Beberapa usia lanjut yang mengalami kelelahan setelah beraktivitas fisik akan membuat tidurnya menjadi lebih cepat dan nyenyak, tetapi ada pula usia lanjut yang mengalami kelelahan malah membuat kebutuhan waktu tidur menjadi berkurang ${ }^{24}$. Faktor lingkungan yang dapat mempengaruhi kualitas tidur seseorang adalah suara atau kebisingan, suhu ruangan dan pencahayaan. Keadaan lingkungan yang nyaman dan aman dapat mempercepat proses tidur seseorang 25 .

Aktivitas fisik yang dilakukan secara teratur dapat meningkatkan total durasi tidur dan kualitas tidur. Penelitian yang dilakukan oleh Anggarwati dan Kuntarti (2016) menunjukkan bahwa 98 usia lanjut wanita yang rutin mengikuti senam lansia memiliki rerata skor kualitas tidur yang baik daripada yang tidak rutin mengikuti senam lansia. Aktivitas fisik yang dilakukan dengan teratur dapat meningkatkan konsumsi energi, sekresi endorphin dan suhu tubuh yang dapat memfasilitasi tidur dalam proses pemulihan tubuh. Aliran darah yang lancar akan menyebabkan oksigen ke otak menjadi lancar sehingga hal ini dapat mengontrol tekanan darah yang kemudian dapat meningkatkan rasa nyaman saat tidur ${ }^{14}$. Melalui aktivitas fisik yang dapat meningkatkan suhu inti manusia maka sistem termal sirkadian akan mengimbangi peningkatan suhu tersebut dengan menurunkan suhu lebih dari biasanya ${ }^{26}$. Peningkatan suhu tubuh diperlukan oleh hipotalamus untuk melakukan penurunan suhu tubuh yang lebih teratur sehingga dapat meningkatkan kualitas tidur ketika proses pemulihan tubuh. Hal ini dapat berdampak baik terhadap fase tidur Non Rapid Eye Movement (NREM) fase 3 dan 4 usia lanjut yang mulai menurun ${ }^{14}$.

Aktivitas fisik yang dilakukan secara teratur menjaga keseimbangan homeostatis tubuh melalui jalur Hypotalamic Pytuitari Adrenal (HPA) Axis. Pada keadaan ini produksi serotonin, encephalin dan endorphin mengalami peningkatan. Aktivitas fisik menyebabkan cadangan glukosa dalam tubuh berkurang sehingga akan menyebabkan munculnya endorphin. Endorphin yang muncul akan memberikan rasa nyaman, senang dan bahagia. Dalam kondisi rileks maka usia lanjut akan mudah dalam memenuhi kebutuhan tidurnya ${ }^{27}$. Kondisi yang rileks dan nyaman akan mempercepat usia lanjut untuk mampu memulai tidur dengan lebih cepat. Hormon melatonin dibantu oleh serotonin dan endorphin membantu mencapai tidur yang dalam (delta deep) sehingga ketika ada rangsangan dari luar atau dalam usia lanjut akan lebih toleran dan tidak mudah terbangun. Pemenuhan tidur yang cukup akan meningkatkan proses regenerasi sel dan tercapai kebugaran tubuh yang baik. Latensi dan durasi tidur yang cukup akan membuat usia lanjut dapat beraktivitas dengan baik dan tidak mudah mengantuk pada siang hari ${ }^{19}$.

Penelitian lain yang dilakukan oleh Rosdianti et al pada tahun 2018 menunjukkan bahwa terdapat hubungan yang signifikan antara Activity Daily Living (ADL) dengan kualitas tidur pada usia lanjut di PSTW Khusnul Khotimah Pekanbaru. Usia lanjut dengan ADL mandiri cenderung memiliki kualitas tidur yang baik. Melalui aktivitas fisik dapat merangsang aktivitas saraf simpatis dan aktivitas saraf parasimpatis sehingga hormon adrenalin, norepinefrin dan katekolamin menurun ${ }^{17}$. Sistem saraf simpatis diaktivasi ketika beraktivitas fisik yang menyebabkan peningkatan denyut jantung, sedangkan sistem saraf parasimpatis menyebabkan proses pemulihan ${ }^{18}$. Aktivitas saraf parasimpatis akan menyebabkan terjadinya vasodilatasi pembuluh darah yang menyebabkan oksigen ke otak dan seluruh tubuh menjadi lancar sehingga menyebabkan peningkatan relaksasi ${ }^{19}$. Aktivitas fisik yang baik akan menyebabkan tingkat kebugaran yang baik sehingga meningkatkan kualitas tidur menjadi baik ${ }^{17}$.

\section{SIMPULAN}

Berdasarkan hasil penelitian yang telah dilakukan maka dapat disimpulkan bahwa terdapat hubungan antara aktivitas fisik dengan kualitas tidur pada usia lanjut di Desa Sumerta Kelod.

\section{DAFTAR PUSTAKA}

1. Naftali A, Ranimpi Y, Anwar M. Kesehatan Spiritual dan Kesiapan Lansia Dalam Menghadapi Kematian. Buletin Psikologi. 2017; 25 (2), 124-135.

2. Suardiman, P. S. Psikologi Lanjut Usia. Yogyakarta: Gadjah Mada University Press. 2011.

3. Maryam S, dan Rosidawati. Mengenal Usia Lanjut dan Perawatannya. Jakarta: Salemba Medika. 2008.

4. Sharma R, Das K, Randhawa H, Subodh B. Sleep Quality and Its Effect On Activities of Daily Living Among Substance Dependent Subjects. Delhi Psychiatry. 2015; 18 (1), 32-39.

5. Darmojo B. Geriatri (IImu Kesehatan Usia Lanjut). Jakarta: Balai Penerbitan. 2011.

6. Bandiyah S. Lanjut Usia dan Keperawatan Gerontik. Yogyakarta: Nuha Medika. 2009.

7. Malakouti S, Foroughan M, Nojomi M, Ghalebandi M, Zandi T. Sleep Patterns, Sleep Disturbances and Sleepiness In Retired Iranian Elders. International Journal Of Geriatric Psychiatry. 2009; 24 (11), 1201-1208.

8. Potter P, dan Perry A. Buku Ajar Fundamental Keperawatan: Konsep, Proses dan Praktik. Jakarta: EGC. 2010.

9. Potter P, dan Perry A. Buku Ajar Fundamental Keperawatan: Konsep, Proses dan Praktik. Jakarta: EGC. 2005.

10. Maas L. Asuhan Keperawatan Gerontik. Jakarta: EGC. 2011.

11. Triyadini, Asrin, Upoyo A. Efektifitas Terapi Massage Dengan Terapi Mandi Air Hangat Terhadap Penurunan Insomnia Lansia. Jurnal Keperawatan Soedirman. 2010; 5 (3), 174-181.

12. Bouchard C, Blair S, \& Haskell W. Physical Activity and Health 2nd Edition. United States: Human Kinetics. 2012.

13. Khasanah K, \& Hidayati W. Kualitas Tidur Lansia Balai Rehabilitasi Sosial "MANDIRI" Semarang. Jurnal Nursing Studies. 2012; 1 (1), 189-196. 
14. Chennaoui M, Arnal P, Savet F, leger D. Sleep and Exercise: A Reciprocal Issue? Sleep Medicine Review. 2014; 20, 1-14.

15. Tatum J. The Relationship Between Physical Activity and Sleep. Texas: University of North Texas. 2010.

16. Nina N, Kalesaran A, \& langi F. Hubungan Aktivitas Fisik dengan Kualitas Tidur Pada Masyarakat Pesisir Kota Manado. KESMAS. 2018; 7 (4), 1-7.

17. Rosdianti $Y$, Herlina, Hasanah O. Hubungan Activity of Daily Living (ADL) dengan Kualitas Tidur pada Lansia di PSTW Khusnul Khotimah Pekanbaru. JOM FKp. 2018; 5 (2), 660-666.

18. Khomarun, Nugroho M, Wahyuni E. Pengaruh Aktivitas Fisik Jalan Pagi Terhadap Penurunan Tekanan Darah pada Lansia Dengan Hipertensi Stadium I di Posyandu Lansia Desa Makamhaji. Jurnal Terpadu IImu Kesehatan. 2013; 3 (2), 106-204.

19. Komsiatiningsih. Pengaruh Program Rutin Exercise Aerobik dan Pemberian latihan Relaksasi Otot Progresif Terhadap Latensi dan Durasi Tidur Pada Lansia di UPT PSIU Magetan. Fakultas Keperawatan Universitas Airlangga Surabaya . 2015.

20. Azizah, dan Ma'rifatul I. Keperawatan Lanjut Usia. Yogyakarta: Graha IImu. 2011.

21. Kemenkes RI. Analisis Lansia di Indonesia. Jakarta: Kementerian Kesehatan RI. 2017.

22. Putra K, Kurniasari, M, Purnamasiwi A. Analisa Hubungan Aktivitas Fisik Terhadap Kondisi Fisik Lansia di Desa dan Kota. Seminar Nasional Pendidikan Jasmani. 2018; 235-243.

23. Aimul. Pengantar Kebutuhan Dasar Manusia : Aplikasi Konsep dan Proses Keperawatan. Jakarta: Salemba Medika. 2006.

24. Rudimin, Harianto T, Rahayu W. Hubungan Tingkat Umur Dengan Kualitas Tidur Pada Lansia di Posyandu Permadi Kelurahan Tlogomas Kecamatan lowokwaru Malang. Nursing News. 2017; 2 (1), 119-127.

25. Hidayat A. Pengantar Kebutuhan Dasar Manusia Aplikasi Konsep dan Proses Keperawatan Edisi 2. Surabaya: Salemba Medika. 2009.

26. Gilbert S, Van de Heuvel C, Ferguson S, \& Dawson D. Thermoregulation as a sleep sigalling system. Sleep Medicine Reviews. 2004; 8 (2), 81-93.

27. Mahardika J, Haryanto J, Bakar A. Hubungan Keteraturan Mengikuti Senam Lansia dan Kebutuhan Tidur Lansia di UPT PSIU Pasuruan di Barat lamongan. Indonesian Journal of Community Health Nursing. 2012; 1 (1), 1-11.

28. Pangulu R. Hubungan Aktivitas Fisik dengan Kejadian Insomnia pada Usia lanjut di Panti Sosial Tresna Werdha Yogyakarta Unit Budi Luhur Kasongan Bantul. Stikes Aisyiyah Yogyakarta. 2015.

29. Kuntarti, dan Anggarwati ES. Peningkatan Kualitas Tidur Lansia Wanita Melalui Kerutinan Melakukan Senam Lansia. Jurnal Keperawatan Indonesia. 2016; 19 (1), 41-48. 